\title{
Implementation of the Inter-Agency Collaboration in Vocational Education of Students with Learning Disabilities towards Preparation of Career Experience
}

\author{
Noraini Abdullah ${ }^{1}$, Mohd Hanafi Mohd Yasin ${ }^{1} \&$ Nur Aishah Abdullah ${ }^{1}$ \\ ${ }^{1}$ Faculty of Education, Universiti Kebangsaan Malaysia, Selangor, 43600, Malaysia \\ Correspondence: Noraini Abdullah, Faculty of Education, Universiti Kebangsaan Malaysia, 43600 UKM Bangi, \\ Selangor, Malaysia. Tel: 60-13-778-3794. E-mail: meknogha70@yahoo.com
}

Received: February 8, 2015 Accepted: March 17, 2015 Online Published: June 5, 2015

doi:10.5539/ass.v11n18p183 URL: http://dx.doi.org/10.5539/ass.v11n18p183

\begin{abstract}
Inter-agency collaboration is a very important element in the success of vocational education programs for students with special needs, especially for students with learning disabilities. Inter-agency collaboration is a team consisting of students, parents, school representatives and representatives of outside agencies involved in implementing, coordinating and developing service plans for students with special needs. However, the implementation of inter-agency collaboration with schools has remained at low levels. Therefore, this study was undertaken to explore the implementation of inter-agency collaboration and the obstacles faced by teachers in vocational education of students with learning disabilities towards career experience preparation. This study used a qualitative approach with case study design. Data were collected using interviews involving 10 teachers from vocational education in 6 Integration Program with Learning Disabilities (IPLD) schools. The findings show that there is inter-agency collaboration implemented with the schools involved but the implementation is not comprehensive. Results from interviews show that there are several obstacles in the implementation of inter-agency collaboration in terms of student attitude, parental attitude, and attitude of employers, financial problems and lack of information about the implementation of vocational education in IPLD. This study is expected to assist schools in implementing inter-agency collaboration to provide the best service to enhance the skills and careers of students with special needs especially students with learning disabilities.
\end{abstract}

Keywords: inter-agency collaboration, vocational education, students with learning disabilities, career experience preparation

\section{Introduction}

Transformation in vocational education through the Education Development Plan (MECC) 2013-2025 states that vocational education should be implemented because this change will provide skilled workforce trained to meet the needs of the country to enter the job market. In this case, vocational education for students with special needs, especially for students with learning disabilities should not be marginalized because by following the skill and technical field, and by being exposed with practical training from the school years will enable them to adapt easily to the working environment. Studies by (Lokman, Nurul Qistin, \& Mohd Hanafi, 2009; Ramlee Mustapa, 2004; Krajewski \& Callahan, 1998) show that vocational education can help students with special needs to obtain the necessary skills and serve as a preparation for them to compete in the job market. In implementing vocational education for students with special needs, especially for students with learning disabilities, inter-agency collaboration is a very important element.

Inter-agency collaboration is defined as a team of students, parents, school representatives and representatives of outside agencies involved in implementing, coordinating and developing transition program service plans based on vocational training for students with special needs (Wright, 2011). According to Kohler (1996) in Transition Taxonomy Model, collaboration between agencies is the involvement of agencies in transition program comprising community as employers and employment agencies. Collaboration is established as a service delivery system that has the role, responsibility, communication strategies, and other collaborative action that seeks to develop curriculum and program development and service delivery system (Benz, Lindstrom, \& Yovanoff, 2000; Kohler, 1996). Through collaborative practices, educational and adult service providers address 
opportunities for individual students, as well as community issues that influence opportunities and services for students in general. The purpose of these collaborative activities is to implement an integrated system that addresses the lifelong learning and support needs of a community's members. Devlieger \& Trach (1999) found that inter-agency collaboration and support for individual students in transition and their families is an important factor, it facilitates achievement of transition goals, and when done poorly, it limits or impedes those goals.

Collaboration between agencies does not only expose students to the community but also provides career training experience directly and meaningfully for students (Kohler \& Field, 2003). Career preparation experience is designed to help young generation to be prepared and to succeed after school education, careers and be independent. Preparatory activities for career experience includes career awareness activities, career exploration, career assessment in teaching and learning, employability skills and career-based training to give students an opportunity to explore various careers and identify career interests (Blackmon, 2008). Transition to adult model by Blackmon (2008) states that the agencies should treat each student as an individual and is committed to meet each student's needs by determining the types of services and agencies involved. Collaboration between agencies is important to provide experience for students with learning disabilities, especially for collaboration with the community. Landmark, Ju, and Zhang (2010) propose to help students get the maximum benefits and can generalize skills in a variety of environments, experience-based on school and community-based experience including work environment should be exposed to the students. Johnson et al. (2002) state that the provision of school programs and community-based on career experience should be implemented as one of the factors that assists students to success in the workplace.

Previous studies showed that inter-agency collaboration is very important especially for students with special needs. The study by Zainuddin (2004) found that collaboration with the community in education is very important to enhance the skills and career of groups with special needs. The community or group in his study involved the government, non-governmental organizations, employers and individuals. He outlined the three roles of the society; i) change the negative perception towards the ability of people with disabilities; ii) improve systems and practices implemented that involved groups with special needs; and iii) enhance support and cooperation for those with special needs to ensure that they have careers. This is consistent with the key objectives and functions of vocational education for students with special needs which is to apply skills that can give them an opportunity to get a job to live independently (Walls \& Fuiimer, 1997).

Studies by Kohler (2003); Blackmon (2008); Wright (2011) showed that student success in completing their education program is dependent on the collaboration aspects. The ability of educators, support from parents, community agencies and employers in the process of providing them with the skills, understanding and career opportunities to make them live independently, productively and motivated to carry out their responsibilities as members of society. In this case, various parties including school administrators, teachers, parents, community agencies and community (Landmark et al., 2010; Noonan et al., 2012; Wright, 2011; Zhang et al., 2005) should play their roles to implement collaboration effectively.

Based on the above studies, it is clear that the cooperation of special education teachers by creating an inter-agency collaboration is an initial preparation for those with special needs to enter into a career. Cooperation and collaboration between the listed agencies is an effective practice to facilitate the vocational training based transition program for students with learning disabilities to face their adult life after they have completed their school years. The focus of this study is to explore the implementation of inter-agency collaboration and identify the obstacles faced by teachers in implementing vocational education for students with learning disabilities towards preparation of career experience.

\section{Statement of the Problem}

Collaboration between agencies is an important element to ensure the success in implementing vocational education. Review by Kohler (2003) and Blackmon (2008) stated that the success of students with special needs in completing education program is dependent on the aspect of collaboration. However, the results show that there is a lack of evidence of the implementation of collaborative practices in schools in order to enhance inter-agency collaboration with schools in implementing the transition program based on student's vocational training (Test, 2009; Benz, Lindstrom, \& Yovanoff, 2000).

Previous studies showed that there are problems in the implementation of inter-agency collaboration such as (a) lack of shared knowledge and vision by students, parents, and school and agency staff around students' post-school goals and the transition resources necessary to support students' needs and interests (Johnson, et al., 2002); (b) lack of shared information across school and community agencies, and coordinated assessment and planning processes, to support integrated transition planning (Benz, Johnson, Mikkelsen, \& Lindstrom, 1995); (c) 
lack of meaningful information on anticipated post-school services needed by students and follow-up data on the actual post-school outcomes and continuing support needs of students that can be used to guide improvement in systems collaboration and linkages (Hasazi et al., 1999; Johnson \& Sharpe, 2000); (d) lack of effective practices for establishing and using state and local inter-agency teams as a means for capacity building in transition collaboration and systems linkages; and (e) lack of coordinated eligibility requirements and funding for agency services (Luecking \& Crane, 2002).

Study by Grigal and Neubert (2004), showed that parents and teachers involved in the vocational training based transition program have less information on career options in the community. The study by Norshidah, Zuria and Zalizan (2003) revealed that parents need information related to the issue of children and their special needs, related services, educational opportunities, advice and legal aid, and others. However, the lack of coordination between service supervisors and school as well as the recipients of the services complicates the inter-agency collaboration (Norshidah et al., 2003; Wright, 2011). Furney et al., (1997) mention that lack of meaningful roles for students and parents in the transition decision-making process that respects students' emerging need for independence and self-determination and parents' continuing desire to encourage and support their children during the emancipation process that is part of becoming a productive, contributing young adult.

In implementing vocational education, students with special needs should be exposed to the real situation of the working environment so that they can practice what they have learned in school. However, negative perceptions of employers towards students with special needs make it difficult for them to be accepted to undergo training or work by the employers. The study by Singley (2003) showed that negative perceptions and attitudes of employers are the main obstacles for those with special needs to get a job. The same goes for people who have perceptions and negative attitudes towards those with special needs (Lokman et al., 2009). The attitude of students with special needs is also a constraint for their practical training. Feeling of inferiority, not confident with their ability, unable to adapt and having difficulty in interacting with others cause the employers to find it difficult to accept the students with special needs (Safani, Mohd Salleh, \& Arief, 2000 \& Sarimah, Norshahril, \& Rohana, 2012). Examination of previous studies indicates that there are obstacles in implementing inter-agency collaboration with schools.

\section{Purpose of the study}

The purpose of this study is to explore the implementation of inter-agency collaboration and identify the obstacles faced by teachers in implementing vocational education for students with learning disabilities towards preparation of career experience.

\section{Research Methodology}

This study used a qualitative approach and case study design. Case study was chosen for this study to explore, interpret and gain a deeper understanding of the case but not to test a hypothesis. The study involved of six schools in the Integration Program with Learning Disabilities (IPLD) in four states, namely Johor, Melaka, Selangor and Kuala Lumpur. IPLD was selected because it was the first school to begin the implementation of vocational education for students with learning disabilities in Malaysia.

This study used purposive sampling method. Through this technique, the participants selected based on a participant that can provide in-depth information for the purpose of fostering a growing theoretical basis and sequence (Strauss \& Corbin, 1998; Marshall \& Rossman, 1999). Through purposive sampling, it will be able to assist in accessing research sites more easily and get more detailed information and are able to answer the research questions (Gall et al., 2003). The participants in this study were between the aged of 25 to 45 years and have experience teaching between 5 to 20 years. The participants selection is based on meeting the needs of the research questions, willing to work, willing to be interviewed and can provide the required information.

An interview protocol was developed based on previous studies and adapted from Taxonomy for Transition Programming (Kohler, 1996). Interviews in this study used checklists and questions in the form of semi-structured interview protocol as to build the confidence of the researcher. To obtain the necessary information, the interviews were carried out twice. A total of 10 teachers from vocational education in IPLD were involved in this interview. The first interview was to obtain general information regarding the implementation of the collaboration and the problems faced in the implementation of inter-agency collaboration in IPLD. Once the themes rose, researchers carried out the second interview to get information in more depth. The interview was around 45 minutes individually. In addition, all important information was recorded in MP3 and notebook. All interviews were audio recorded and transcribed. All data that has been obtained was processed, analysed and managed using a computer program from ATLAS.ti 7.5.2. to get the themes and to answer the research questions 


\section{Findings}

\subsection{Inter-Agency Collaboration Services}

Findings indicate that there are some collaboration services conducted by the schools with agencies involved in implementing vocational education for students with learning disabilities towards career experience preparation.

\subsubsection{School Collaboration with Institutions of Continuing Education}

School collaboration in PPKIBP with institutions of continuing education provides opportunities for students with learning disabilities to further their education. The findings show that all schools implement collaboration with institutions of continuing education. Collaboration with continuing educational institutions is carried out with the government, namely Community College, Giat Mara, Johor Education Foundation (YPJ), and Melaka Education Foundation (YPM), while collaboration with the private sector is run by private colleges such as Max College, Bagus College and Segi College. The findings show that the collaboration carried out in Giat Mara and Community College only involve short-term courses only as specified by G10S6 “... this school carries out continuing education with Giat Mara College. There many short term courses based on skills are organized and students will be given a certificate. Generally that is the only thing we do". The same matter was also agreed by G4S2 who carry out collaboration with the local Community College for short courses "... we have done the same with Ledang Community in ...they invited us there to learn how to make bread, make cookies and make roti canai ... but these course are for short-term only". The interview data revealed that students with learning disabilities could not continue their studies in the long term because they do not have the Malaysian Certificate of Education (SPM). This is explained by G1S1 "...I go to Giat Mara in Muar. He said because these things involve electricity, this thing is dangerous. He wants the students to have at least SPM. Most of our students do not have SPM so it is difficult to enter there la ...".

The findings also indicate collaboration carried out with the Buying Seats Program which is collaboration with the public and private institutions of vocational education and the industry. This program provides opportunities for students with special needs to gain skills and knowledge and gain experience of studying in private institutions and industry in line with the Key Performance Indicator (KPI) of the Technical and Vocational division (BPTV). Students with special needs involved are those aged 16 to 18 years. The findings show that most students with learning disabilities who attend the Buying Seats Program do not continue their studies in the skills area they learn in school because the skills area is not offered by the institutions involved. Among the skills offered are air conditioning maintenance, electrical wiring and automotive. This is explained by G4S2 who mentioned "... there is a student of this school who have entered Melaka Education Foundation, electrical wiring course, so it is no longer the same field in school because there she learned to cook" and this is supported by G1S1" He entered Johor Education Foundation College but not in agriculture, he got the air-cond course, so it is not the same field". Collaboration with higher education institutions are also carried out by inviting the institutions to give presentations and lectures related to the courses offered, teaching methods and opportunities offered to continue their education for students with learning disabilities as stated by G10S6 “... we also carry out career talks, for example, we call the officers from the Community Colleges to give talks to parents. Whatever skills their children need, all are included".

\subsubsection{School Collaboration with the Public and the Private Sector}

School collaboration with the private and public sector plays an important role in providing services to students in PPKIBP. The findings show that only one school, namely School 1, actively pursues collaboration with the public and the private sector. School 1 has implemented collaboration with PELADANG, Department of Irrigation and Drainage (DID), Federal Agricultural Marketing Authority (FAMA) and the Department of Agriculture. This is explained by G3S1"... we carry out this collaboration with various parties such as PELADANG who supply fertilizer". We also work with DID to supply water, drain cleaning and so on. Add G3S1"...Department of Agriculture helps in terms of advisory services, supplying seeds and fertilizer. FAMA on the other hand is more towards giving advice related to marketing". The involvement of the private sector also plays an important role in ensuring that vocational education taught in schools has continuity with the requirements of the job market. The findings show that School 1 implemented collaboration with the private sector related to agriculture such as advisory and maintenance services. This was stated by G1S1"...we are involved for instance consultant Azura she is more focused on providing advisory services on crop fertilization, consultant Haikal he is more towards maintenance services or plant care, so we are always in touch". This active collaboration is due to the school's GPKPK who is constantly in contact with the public sector to gain assistance in implementing the Special MPV (Vocational Subject) of agriculture in his school. 


\subsubsection{School Collaboration with Community}

Schools collaboration with the community is very important so that students with learning disabilities can foster self-confidence, can interact with the community and can get rid of the feeling of shyness in themselves. The findings show that only School 1 carries out collaboration with the local community. This is because School 1 is located in an agricultural area and this has facilitated the school to keep in touch with the community in carrying out the Special MPV (Vocational Subject) of agriculture. Collaboration with the community is carried out with a few entrepreneurs in the surrounding villages and the collaboration carried out is in terms of encouragement and motivation, visits, becoming partners and advisory services, as mentioned by G3S1 “... like Encik Musa .. he provided a lot of motivation, encouragement for our kids, we bring our kids to have a look for themselves at his crops, sometimes he himself would come and have a look what are the problems with our plants ...". In addition, School 1 also carry out collaboration with a few entrepreneurs who have been successful in the villages nearby as stated by G3S1 "I have made contact with some entrepreneurs in the village who are successful... there are 5 or 6 or 10 of them, then I create network so that they would know our problems and we refer our problems to them”. G3S1 also added “... we do bring our students to go to the place aa .. papaya orchard. We work together with the entrepreneurs ...aa ... the farms aa ...to teach our kids the way aa .. caring for vegetables, planting methods. Chilli plants, paddy fields as well".

\subsubsection{School Collaboration with Employers}

The findings show that only School 1 carries out collaboration with employers. Collaboration with employers is necessary to familiarize students with learning disabilities with experience of real situations when they go out to work later. In this case, the teachers themselves were the ones who play the role to ensure that the students with learning disabilities can be accepted by the employer to undergo training in their place.

This was stated by G2S1".. we carry out practical training at Teo garden who do landscaping near Parit Bunga, Muar, the employer accepts 2 of our students to carry out the practical there". The school also brings the students to the vegetable gardens and farms to experience for themselves the real experience of how agricultural activities are carried out. This is explained by G2S1 “... we do bring the students to go to papaya orchards, vegetable garden. We work with the farm operators to teach these students how to care .. for vegetables, planting methods, such as chili plants, long beans and paddy." The teachers also meet with employers to introduce these students with learning disabilities as stated by G2S1 "We met with the operators of farms, we ask them ourselves about their needs, employment opportunities for our students to continue aa .. meaning if they have places...".

\subsubsection{School Collaboration with NGOs}

The findings revealed that School 5 is the only school that carries out collaboration with NGOs, namely the Sunway Group. At School 5, there is a Backup Program that is created for students with learning disabilities to carry out practical outside the school. For students with learning disabilities who are involved with the components of handicraft, collaboration is carried out with GOLD (Generating Opportunities for Learning Disabilities) which is located in 3C Subang Jaya Municipal Council (MPSJ). MBP involved in this Backup Program will be in GOLD for three days a week that is on Mondays, Tuesdays and Thursdays from 8.00 am to $1.00 \mathrm{pm}$. Through this Backup Program, students with learning disabilities are taught various skills such as cooking skills and handicraft skills as well as career skills by teaching staff from Sunway Group as stated by G9S5 “...The Backup Program teachers do teach them about culinary skills, Drawing skills and Handicrafts (LKT) ....all the skills, personal and social skills are all there so that when they get there they not only acquire manual skills, skills that exist but social skills, how to interact with people, how to dress, cleanliness all they have...". Among the handicrafts produced by the students with learning disabilities in School 5 are ceramics, patched teapots, wood work, stamping cards, notebooks, brush painting and water painting and these crafts are made if there is demand. This is explained by G9S5 "... Ceramics, patched teapot, wood work all there .. timber and then emm .. cards, notebooks...these are to make stamping cards. Notebook .. and what else ...aa... brush painting, water painting but we make in our case if there is a request to create la."

\subsection{Obstacles in Implementing Inter-Agency Collaboration}

The findings show that there are several obstacles to implementing inter-agency collaboration in vocational education of students with learning disabilities towards preparation of career experience.

\subsubsection{The Attitudes of Students}

The attitudes of students that are too dependent on teachers are obstacles to implementing inter-agency collaboration. Findings from interviews with G4S2 revealed that he had sent students to undergo job training 
outside of school but the students find it difficult to adapt resulting in the collaboration with the employers could not be continued anymore or temporarily postponed. This is explained by G4S2 "... before this, I have sent students to caterers but he wanted us to be together with them. .. he wants us to be totally there, which is impossible to do ...". This matter is also acknowledged by G5S3 "If the teacher is not there ... they feel not confident, that's the problem facing our special education students. Indeed it's done before la."

\subsubsection{The Attitude of Employers}

In addition, the study found that the attitude of employers who find it difficult to accept students with learning disabilities to undergo practical at their place has resulted in PPKIBP unable to perform collaboration with employers. Negative perceptions of employers such as having lack of confidence in the ability of special education students and employers' own attitudes who do not understand these students are obstacles in implementing collaboration. This was stated by G4S2 "He did not want this kind of student. They can actually do the work but the people say they are slow, they need people to guide them ...". The same thing was also acknowledged by G5S3 "They did not accept him because he was in special education...aa...that's it...they cannot accept".

\subsubsection{The Attitude of Parents}

The attitude of parents is also a barrier in implementing inter-agency collaboration. The study found that most parents only come to school during the registration day and during the open day. The findings show that most parents are busy with their own affairs causing them not to have time to come to school. This is certified by G5S3 “... parents came there also some who come but not many because they are busy especially working parents". The findings also show that the parents agree with the vocational education activities undertaken for their children but they are less keen to participate. This was stated by G9S5 "...it is a bit difficult if we want to involve the parents particularly involving programs outside of school. Most of them will leave it totally to the teachers".

\subsubsection{Lack of Information}

Collaboration between schools and outside parties also could not be implemented because they lack information about vocational education carried out in PPKIBP such as those run by other organizations like the Association of Down Syndrome, Autism Society which have their own associations that conduct various activities to benefit the members of the association. This is explained by G7S4 “... in my opinion, outsiders do not know .. do not get aa .. information about the schools that run these MPV programs. Specially parents to get information .. so if we want to, we have to have a a. like approval from the ministry that would allow us to create a program we can reveal to NGOs to anywhere so .. they do not know anything".

\subsubsection{Financial Problems}

The findings show that financial factors are problems in implementing collaboration with outsiders because the teachers have to fork out their own allocation to send students with learning disabilities to undergo practical training outside the school area. This was stated by G4S2 “... our constraint is that we have to send them, then we have to go back to school and then go back again after that to fetch them....previously we did it but this year...because we have some financial problems if we go out we incur cost to send the students, to fetch them also require some money." This is supported by G5S3 “... indeed we do not have provisions to carry out activities, we only rely on the PCG money only".

\section{Discussion}

Based on the findings, there is inter-agency collaboration carried out by the school in Integration Program with Learning Disabilities (IPLD) towards career preparation of students with learning disabilities. However, collaboration between the agency and the school was not conducted comprehensively. It is only collaboration with continuing education institutions which is carried out by all the schools involved in this study. This is because all the schools involved with the Buying Seats Program. The Buying Seats Program is collaboration between public institutions vocational education with the private sectors and industry. The purpose of this program is to provide opportunities for students with special needs to acquire skills and knowledge in the field of academic and vocational fields. In addition to their learning experience in private institutions and industry, they also have the opportunity to get a job after they graduate. However, study shows that collaboration with public institutions of further education only involved short term courses. This is because students with learning difficulties do not have Malaysian Certificate of Education (MCE) qualifications to enable them to continue their studies for long-term courses. Findings from interviews with teachers suggested that students with learning 
disabilities are given the flexibility to pursue education in public institutions of continuing education despite the fact that the students with learning disabilities do not have MCE certificate.

The findings also showed that only one school implemented collaboration with the government and the private sector, communities and employers. Active inter-agency collaboration with the school was due to the role played by the Special Education Senior Assistant Teacher of this school who is always trying to carry out collaboration with the relevant authorities to ensure that vocational education can be successfully done in preparation for career experience for students with learning disabilities. These findings are consistent with studies by (Shafie, 2002; Juairiah, 2000) which states that having impeccable support services would enable a curriculum to be implemented effectively. For schools that do not implement inter-agency collaboration, there are several barriers that prevent them from implementing collaboration such as the attitude of students who are too dependent on their teachers. This poses a problem for the teachers because they have to send, wait and bring back all the students. The attitude of not having confidence in self and difficulty in socializing results in the teachers being unable to send the students to undergo vocational training outside the school area. Study by Safani et al., (2000) stated that the main problem of persons with disabilities (PWDs) is their own attitude where they prefer to be together with friends of the same fate in any field that they are involved in. Similarly, feeling of inferiority, not confident with their own ability, unable to adapt and difficulty in interacting with others (Safani et al., 2000; Sarimah et al., 2012) cause them to find it difficult to undergo training outside of school and subsequently entering the career world.

This findings also suggest that students with learning disabilities receive training especially in self-management skills and teamwork skills so that they can enhance their confidence before they enter the career. The study by Taylor (2005) stated that training skills are essential as preparation for individuals to compete in the working environment. This shows that training skills need to be learned and subsequently dominated by the special needs so they can get a chance to compete in the job. Findings also indicate that employers are not interested to accept students with learning disabilities to undergo training at their place of work. This is an obstacle for the schools in Integration Program with Learning Disabilities (IPLD) to implement collaboration with employers. The findings of this study support the findings by Singley (2003) which states among the main obstacles for people with special needs to get a job is the perception and negative attitudes of employers. In this case, the employer cannot discriminate students with learning disabilities because this abilities are permanent. Instead, the employers must look into the ability they have. Employers also need to strive to understand about learning difficulties so that the students with learning disabilities are more willing to accept their practical training and will have a chance to get a job based on skills they have. Therefore, teachers should strive to highlight the talent and potential that exists in students with learning disabilities so that they are readily accepted by employers.

The next hurdle is the attitude of parents in implementing collaboration between agencies and the school. The findings show that parents are too busy with their own affairs which result in them not having the time to get involved with the activities organized by the school. Study by Sanbagavali (2001) found that most parents who are involved in special education plays a passive role in the program outside the classroom. Therefore, parents should play an important role in ensuring inter-agency collaboration with the schools can be implemented more effectively. Parental involvement is identified as being able to promote the social, emotional, physical, and academic aspects as well as improvement in occupational skills among students. The success of family involvement gives great meaning to the collaboration between parents, students, school authorities and agencies involved (Blackmon, 2008; Grigal et al., 2004; Morningstars et al., 2012).

Financial factor is also one of the constraints of the school to implement inter-agency collaboration. The findings show that the teachers had to fork out their own money to send the students to undergo vocational training outside the school area. In this case, the school needs to work together with the parents to ensure the activities planned for students with learning disabilities can be implemented successfully, especially in the implementation of vocational education in Integration Program with Learning Disabilities (IPLD). Similarly, information about vocational education implemented in Integration Program with Learning Disabilities (IPLD) should be disseminated to the public so that they can get involved to help the schools in the success of vocational education especially for students with learning disabilities. Hence, the collaboration between the service providers and communication and partnership between the parents, companies, agencies in the community, teachers and school authorities is the key to successfully implement the transition and career development activities.

Based on the findings of this study, result showed that the implementation of inter-agency collaboration is still at a low level. Hence, the collaboration between the service provider and communication and partnership between the parents, companies, agencies in the community, teachers and school authorities is a key to the success of the transition and career development activities (Jamaliah, Rohana, \& Aede Hatib Musta'mal, 2012; Landmark, Ju, 
\& Zhang 2010; Kohler \& Field, 2003). In this case, teachers should play an active role to ensure the success of the implementation of inter-agency collaboration. Taylor (2005) and Wallace (1997) state that teachers play a very important role as designers, builders and appraisers in educational programs and should be regarded as a program manager in the group education program (Taylor, 2005; Wallace, 1997).

\section{Conclusion}

The results showed that there is inter- agency collaboration implemented in Integration Program with Learning Disabilities (IPLD) but its implementation is not comprehensive because there are several obstacles faced by teachers in carrying out the vocational educational. Most schools only carry out collaboration with continuing education institutions. This is because the schools provide opportunities for students with learning disabilities who have been selected to further their studies as preparation for a career. However, only one school is actively conducting inter-agency collaboration which is the school that implements the Special MPV (Vocational Subject) of agriculture. For other schools, they face barriers in implementing collaboration because of several factors such as the attitude of students with learning disabilities themselves, attitudes of parents, attitude of employers, financial problems and lack of information. Therefore, all parties including schools, teachers, parents, communities and employers should jointly involve to ensure the implementation of inter-agency collaboration can be implemented successfully. Therefore, in this regard, efforts should be made primarily for the parties responsible to ensure that inter-agency collaboration can be implemented more effectively in vocational education in Integration Program with Learning Disabilities (IPLD) towards preparation of career experience. Implications of this study indicate that the development of vocational education curriculum should involve planning of requirements for support services that include facilities of resources and expertise such as advice, guidance and coaching to ensure the effective implementation of a curriculum. Implications of this study indicate that various parties such as school administrators, teachers, parents, and community agencies should implement effective collaboration to ensure students with learning disabilities gain the skills, understanding and jobs. Furthermore, the role of teachers is important for example in paying a visit to the schools that have successfully implemented a collaboration with the agency so that the knowledge and experience gained can be practiced in their respective schools. Moreover, teachers should work to establish a collaboration with various parties such as a joint venture especially in the field of vocational education, to get advice and work to highlight the existing potentials in students with learning disabilities. The collaboration can prepare the students mentally and physically before entering the working world.

\section{References}

Benz, M. R., Johnson, D. K., Mikkelsen, K. S., \& Lindstrom, L. E. (1995). Improving collaboration between schools and vocational rehabilitation: Stakeholder identified barriers and strategies. Career Development for Exceptional Individuals, 18(2), 133-144. http://dx.doi.org/10.1177/088572889501800207

Benz, M. R., Lindstrom, L., \& Yovanoff, P. (2000). Improving graduation and employment outcomes of students with disabilities: Predictive factors and students perspectives. Exceptional Children, 66, 509-529.

Blackmon, D. (2008). Transition to adult living: An information and resource guide. California Services for Technical Assistance and Training (CalSTAT California Department of Education 2008).

Devlieger, P., \& Trach, J. (1999). Meditation as a transition process: The impact on post school employment outcomes. Exceptional Children, 65, 507-523.

Furney, K. S., Hasazi, S. B., \& Destefano, L. (1997). Transition policies, practices, and promises: Lessons from three states. Exceptional Children, 63, 343-355.

Gall, M. D., \& Gall, J. P. (2003). Educational Research: An Introduction. United State Of America: Pearson Education.

Grigal, M., \& Neubert, D. A. (2004). Parent's in- school values \& post- school expectations for transition-aged youth with disabilities. Career Development and Transition for Exceptional Individuals, 27, 65-85. http://dx.doi.org/10.1177/088572880402700105

Hasazi, S. B., Furney, K. S., \& DeStefano, L. (1999). Implementing the IDEA transition mandates. Exceptional Children, 65(4), 555-566. http://dx.doi.org/10.1177/001440299906500409.

Jamaliah, M. J., Rohana, H., \& Aede Hatib, M. (2012). The role of technical and vocational education in Career Development. Journal of Technical, Vocational \& Engineering Education, 5, 28-34.

Johnson, D. R., \& Sharpe, M. N. (2000). Results of a national survey on the implementation transition service requirements of IDEA of 1990. Journal of Special Education Leadership, 13(2), 15-26. 
Johnson, D. R., Stodden, R., Emanuel, E., Luecking, R., \& Mack, M. (2002). Current challenges facing secondary education and transition services: What research tells us. Exceptional Children, 68(4), 519-531. http://dx.doi.org/10.1177/001440290206800407

Juairiah, J. (1996). Kajian perancangan dan pelaksanaan khidmat sokongan bagi kelas bermasalah pembelajaran di sebuah sekolah rendah di negeri Selangor Darul Ehsan. Latihan Ilmiah Sarjana Muda Pendidikan Khas. Bangi: Universiti Kebangsaan Malaysia.

Kohler, P. D. (1996). Taxonomy for transition programming: Linking Research to Practice. Champaign, IL: Transition Research Institute. Urnana. University of Illinois.

Kohler, P. D., \& Field, S. (2003). Transition-focused education: Foundation for the Future. The Journal of Special Education, 37(3), 174-183. http://dx.doi.org/10.1177/00224669030370030701

Krajewski, J., \& Callahan, J. (1998). Service-learning: A strategy for vocational training of young adults with special needs. The Journal for Vocational Special Needs Education, 34-38.

Landmark, L. J., Ju, S., \& Zhang, D. (2010). Substantiated best practices in transition: Fifteen plus years later. Career Development for Exceptional Individuals, 33, 163-176. http://dx.doi.org/10.1177/08857288103 76410

Lokman, M. T., Nurul Qistin, M., \& Mohd Hanafi, M. Y. (2009). Pendidikan teknik dan vokasional untuk pelajar berkeperluan khas. Jurnal Pendidik dan Pendidikan, 24, 73-87.

Luecking, R., \& Crane, K. (2002). Addressing the transition needs of youth with disabilities through the WIA system. National Center on Secondary Education and Transition Information Brief, 1(6). Minneapolis: University of Minnesota.

Luecking, R., \& Crane, K. (2002). Addressing the transition needs of youth with disabilities through the WIA system. National Center on Secondary Education and Transition Information Brief, 1(6). Minneapolis: University of Minnesota.

Marshall, C., \& Rossman, G. B. (1999). Designing Qualitative Research (3rd ed.). Thousand Oaks: Sage.

Morningstar, M. E., Bassett, D. S., Kochhar-Bryant, C., Cashman, J., \& Wehmeyer, M. L. (2012). Aligning transition services with secondary education reform: A position statement of the division on career development and transition. Career Development and Transition Development for Exceptional Individuals, 35, 132-142. http://dx.doi.org/10.1177/2165143412454915

Noonan, P. M., McCall, Z. A., Zheng, C., \& Erickson, A. G. (2012). An analysis of collaboration in a state-level interagency transition team. Career Development and Transition for Exceptional Individuals, 35(3), 143-154. http://dx.doi.org/10.1177/2165143412443083

Norshidah, M. S., Zuria, M., \& Zalizan, M. J. (2003). Kolaborasi antara ibu bapa dengan sekolah dalam pendidikan khas. Laporan Projek Jangka Pendek GG/009/2001. Bangi: Universiti Kebangsaan Malaysia.

Ramlee, M. (2004). IT and multimedia literacy in technical and vocational education in Malaysia. International Journal of Digital Contents, 2(1), 113-115.

Safani, B., Salleh, A., \& Mohd Arief, I. (2000). Halangan dan masalah yang dihadapi oleh pelajar-pelajar berkeperluan khas dalam latihan kemahiran teknik dan vokasional. Prosiding Seminar Kebangsaan Kepelbagaian Pelajar: Cabaran dan Strategi Pengajaran. Bangi : Universiti Kebangsaan Malaysia.

Sarimah, I., Norshahril, A. H., \& dan Rohana, H. (2010). Halangan orang kurang upaya (pendengaran) di Malaysia mendapat pekerjaan. Fakulti Pendidikan. Universiti Teknologi Malaysia.

Shafie, L. (2002). Program pendidikan khas di Sarawak: Satu penilaian. Tesis Dr Falsafah. Bangi. Universiti Kebangsaan Malaysia.

Singley, S. G. (2003). Barriers to employment among long-term beneficiaries: A review of recent international evidence. Centre for Social Research and Evalution.

Strauss, A. L., \& Corbin, J. (1998). Basics of qualitative research: Grounded theory procedures and techniques. Thousand Oaks: Sage.

Subramaniam, S. a/p. (2001). Kolaborasi antara ibu bapa dan guru kanak-kanak berkeperluan khas di sebuah sekolah menengah di Klang, Selangor. Kertas Projek. Universiti Malaya.

Taylor, A. (2005). What employers look for: The skills debate and the fit with youth perceptions. Journal of Education and Work, 18(2), 201-218. http://dx.doi.org/10.1080/13639080500085984 
Test, D. W., Fowler, C. H., Richter, S. M., Mazzotti, V., \& Kohler, P. (2009). Evidence-based practices in secondary transition. Career Development and Transition For Exceptional Individuals, 32, 115-128. http://dx.doi.org/10.1177/0885728809336859

Wallace, T. L. (1997). The role of paraprofessionals in effective transition programs (PhD Thesis). University of Minnesota.

Walls, R. T., \& Fuiimer, S. L. (1997). Competitive employment, occupations after vocationalrehabilitations. Journal of the American Rehabilitation Counseling Bulletin, 41(1).

Wright, M. P. (2011). A study of the relationship between the interagency collaboration of school counselor in transition planning and the transition outcomes of hard-of-hearing adolescents (PhD Thesis). Capella University.

Zainudin, M. I. (2004). Peranan masyarakat dalam mempertingkatkan kerjaya golongan berkeperluan khas. Seminar Pendidikan Khas. Kejayaan Kanak-kanak Berkeperluan Khas: Perkongsian Bersama, 2, $402-406$.

Zhang, D., Ivester, J., \& Katsiyannis, A. (2005). Teachers' View of Transition Services: Results from a State wide Survey in South Carolina. Education and Training in Developmental Disabilities, 40(4), $360-367$. Division on Developmental Disabilities.

\section{Copyrights}

Copyright for this article is retained by the author(s), with first publication rights granted to the journal.

This is an open-access article distributed under the terms and conditions of the Creative Commons Attribution license (http://creativecommons.org/licenses/by/3.0/). 